\title{
Benefits of and Issues Regarding Sick Child Care for Children and Their Parents
}

\author{
Risako Sakai, Hisako Wada, Mayu Yoshitsugu, Ikuko Sobue* \\ Division of Nursing Science, Graduate School of Biomedical \& Health Sciences, Hiroshima University, Japan
}

Article Details
Article Type: Research Article
Received date: $29^{\text {th }}$ July, 2016
Accepted date: $16^{\text {th }}$ Sept, 2016
Published date: $21^{\text {tt }}$ Sept, 2016

*Corresponding Author: Ikuko Sobue, Division of Nursing Science, Graduate School of Biomedical \& Health Sciences, Hiroshima University, 1-2-3 Kasumi, Minami-ku, Hiroshima 734-8553, Japan. E-mail: sobue@hiroshima-u.ac.jp

Citation: Sakai R, Wada H, Yoshitsugu M, Sobue I (2016) Benefits of and Issues Regarding Sick Child Care for Children and Their Parents. J Comp Nurs Res Care 1: 101. doi: http://dx.doi.org/jenrc/2016/101.

Copyright: (C2016, This is an open-access article distributed under the terms of the Creative Commons Attribution License 4.0, which permits unrestricted use, distribution, and reproduction in any medium, provided the original author and source are credited.

\begin{abstract}
Aim: We surveyed users of sick child care services about the benefits of and issues regarding such care, in order to obtain an insight into its practice.
\end{abstract}

Methods: The study subjects comprised a total of 144 parents whose children had used any of the 15 sick child care facilities in Prefecture A in 2015. These parents consented to participate in the study. Using a quantitative and qualitative method, we surveyed them about their usage of sick child care, care-related requests, as well as perceived benefits and difficulties.

Results: Sick child care was used mainly by children from either double-income nuclear families $(n=123)$ or single-mother households $(n=12)$ because of infectious diseases. The systems for reducing care fees were utilized by $58 \%$ of the single mothers. Subjects viewed the following factors as the benefits of sick child care: 1) a sense of ease achieved through appropriate and professional childcare, 2) being able to work free from anxiety, 3) a reduced burden on children and their normal development, and 4) child raising support for parents. On the basis of difficulties in utilizing sick child care, parents desired improvement in care services, such as an increase in the number of both care facilities and days such care is available, and the capacity to accept children.

Conclusions: The results of this study suggest that, to facilitate sick child care based on the needs of care service users, there is a need to increase the number of care facilities, and expand the capacity to accept children.

Keywords: Benefits, Issues, Sick child care, Support for child raising, Work support

\section{Introduction}

The Japanese government is adopting new systems for child rising in order to respond to changes in the child raising environment resulting from the expansion of women's societal roles and the trend toward nuclear families [1]. These systems aim to provide a wide range of child raising support, including improvement in parents' employment situation in a manner enabling them to manage work and child raising. In particular, as sick children may hinder their mothers from managing work and child raising, the government is promoting the systems for sick child care [2]. Sick child care is a form of nursing care provided temporarily for sick children when they cannot be cared for by their parents at home. In 2012, approximately 490,000 sick children used a combined total of 1,102 sick child care facilities as supporters of working mothers [3]. The role of sick child care is not only to fill in for working parents by looking after their sick children, but also to meet the children's needs [4]. Patents are able to benefit from sick child care in terms of both work and child raising, and such care is also beneficial for their children $[5,6]$. Most of these parents view this type of care as helpful in child raising [6,7]. On the other hand, there have been reports on dissatisfaction with the sick child care systems and care fees, as well as on parents' anxiety about infection [7-9].

Against this background, we surveyed users of sick child care about the benefits of and issues regarding such care in order to obtain an insight into its practice.

\section{Methods}

Study design: Mixed methods research: The study subjects comprised parents whose children had used any of the 15 sick child care facilities in Prefecture A between October and November 2015. These parents consented to participate in the study. In this prefecture, care fees are reduced for families receiving welfare support, those exempt from municipal tax, and those exempt from income taxes. It is possible for service users to utilize sick child care facilities located in municipalities other than their home municipality in accordance with the specified municipal agreement.

As the demographic variables of the subjects, we investigated their age, type of household, employment situation, and monthly household income. We did not survey their residential areas because many municipalities of the studied prefecture had only one sick child care facility. In addition, we investigated the subjects' usage of sick child care (e.g., age and diseases of their children, as well as the costs of and reasons for using such services), annual number of times using care services, whether or not they had ever been unable to use sick child care, and actions taken in such circumstances. We used 15 items regarding the benefits of sick child care (assistance for work, child raising support, and benefits for children), and 14 items regarding care-related requests. Each of these items had 4 possible responses. Furthermore, the subjects were asked to freely write down their opinions and requests concerning sick child care.

We obtained written consent from the managers of the 15 abovementioned nurseries. Staff members of these nurseries then distributed a form describing the study, questionnaire, and self-addressed envelopes to the subjects. A response to the questionnaire was 
interpreted as having consented to participate in the study. In addition, to calculate the response rate, we asked each investigated facility to count the number of questionnaires completed in the facility.

Missing quantitative values were handled according to each question item. Using SAS9.2, we performed exploratory factor analysis and the Wilcoxon signed-rank test. Subjects using and not using the systems for reducing care fees were classified based on their payment of these fees. For qualitative data analyses, the statements in the collected questionnaires were repeatedly reviewed, classified depending on their meaning, and encoded while maintaining the main points of these statements. The encoded data were labeled according to their similarities, based on which the data were divided into subcategories, categories, and core categories. To ensure data reliability, all analyses were performed by 4 researchers.

The study objective/methods and ethical considerations were explained to the above-mentioned managers in written and oral forms, as well as to the study subjects using a request form. The study was conducted with the approval of the ethical review board to which the investigators belonged (27-02).

\section{Results}

Subjects: We distributed a questionnaire to 345 individuals whose children had used any of the 15 nurseries for sick children in Prefecture $\mathrm{A}$, and collected completed questionnaires from 144 of these parents (response rate: $41.74 \%$ ). All collected questionnaires were analyzed.

Quantitative data: Of all subjects, 134 were mothers; 92 and 34 were in their $30 \mathrm{~s}$ and $40 \mathrm{~s}$, respectively (Table 1). Single mothers and those from double-income nuclear families numbered 12 (including 1 subject living with their parents) and 123, respectively. Subjects in full- and part-time positions numbered 71 and 55, respectively. The average daily working time was 7.96 hours $(\mathrm{SD}=1.69)$. In addition, 84 subjects worked on weekends, and 13 were night-time workers. The percentage of those whose monthly disposable income was less than 300,000 yen was significantly higher for single mothers $(91.67 \%$ $[\mathrm{n}=11])$ than people from double-income households $(19.33 \%$ $[\mathrm{n}=23])(\mathrm{P}<0.0001)$. The systems for reducing care fees were used by 43 subjects. In addition, the percentage of those using the systems for reducing care fees was significantly higher for single mothers
$(58.33 \%[\mathrm{n}=7])$ than people from double-income households $(28.33 \%$ [n=34] $)(\mathrm{P}<0.0477)$.

The average number of times using sick child care during the previous year was $4.42(\mathrm{SD}=4.34)$. Most recently, the average number of days using sick child care was $1.89(\mathrm{SD}=1.26)$, with the average number of hours using it per day being $8.09(\mathrm{SD}=1.32)$. The mean age of the children using care services was 3.07 years $(\mathrm{SD}=1.9)$. Among these children, 89 and 79 were male and female, respectively. In addition, 24 parents each placed 2 children in sick child care at any one time. Common diseases included a cold $(n=63)$, pertussis $(n=12)$, and vomiting or diarrhea $(n=11)$. Most children had infectious diseases. The major reason for using sick child care was because of work $(n=142)$. A total of 97 subjects arrived at their workplace late or had to leave early when using sick child care. Furthermore, 141 subjects desired to continue using such care ( Table $-2)$.

During the previous year, 57 subjects had been unable to use sick child care at least once, with the average annual number of times it was unavailable being 2.51 ( $\mathrm{SD}=5.42)$. The reasons for sick child care being unavailable were the maximum capacity of children had been reached $(n=44)$, and financial issues $(n=1)$. The actions taken when sick child care was unavailable included: 1$)$ taking the day off from work ( $\mathrm{n}=64$ [48 mothers and 16 fathers]), 2) placing children in the care of their grandparents $(\mathrm{n}=15)$, and 3$)$ making children stay at home alone $(\mathrm{n}=5)$.

A polychoric correlation matrix was created for the 15 items regarding the benefits of sick child care in order to facilitate the interpretation of these items. The data obtained from these items were then subjected to exploratory factor analysis (unweighted least squares, promax rotation) (Table 3), which led to the extraction of the following 3 factors: 1) a sense of ease achieved through using sick child care, 2) parents' relief, and 3) benefits for children. Both the scale used and these 3 factors showed a polychoric ordinal alpha coefficient of $\geq 0.72$, and an item-total correlation coefficient of $\geq 0.43$, which established the scale's reliability. Significant differences were noted in the scores for these 3 factors $(\mathrm{P}<0.0001)$, with Factor 1 showing the highest point.

\begin{tabular}{|c|c|c|c|}
\hline Indices & Items & $\mathrm{n}$ & $\%$ \\
\hline \multirow[t]{3}{*}{ Age range } & $20 \mathrm{~s}$ & 16 & 11.27 \\
\hline & $30 \mathrm{~s}$ & 92 & 64.79 \\
\hline & $40 \mathrm{~s}$ & 34 & 23.94 \\
\hline \multirow[t]{3}{*}{ Respondents' relationship with their children } & Mother & 134 & 94.37 \\
\hline & Father & 7 & 4.93 \\
\hline & Grandmother & 1 & 0.7 \\
\hline \multirow[t]{6}{*}{ Type of household } & Parents and their children (double income) & 123 & 85.42 \\
\hline & Parents and their children (with only the father working) & 1 & 0.69 \\
\hline & Grandparents, parents, and their children (double income) & 6 & 4.17 \\
\hline & Mother and children & 11 & 7.64 \\
\hline & Grandparents, mother, and children & 1 & 0.69 \\
\hline & Others & 2 & 1.39 \\
\hline \multirow[t]{5}{*}{ Mother's employment status } & Full-time worker & 71 & 52.21 \\
\hline & Part-time worker & 55 & 40.44 \\
\hline & Dispatched employee & 4 & 2.94 \\
\hline & Self-employed business & 3 & 2.21 \\
\hline & Others & 3 & 2.1 \\
\hline
\end{tabular}




\begin{tabular}{|l|l|l|l|}
\hline Working situation & Work hours/day (Mean, SD) & 7.96 & 1.69 \\
\cline { 2 - 4 } & Working on weekends & 84 & 59.15 \\
\cline { 2 - 4 } & Working at night & 13 & 9.42 \\
\hline Monthly disposable income (yen) & $\geq 100,000$ to $<150,000$ & 6 & 4.32 \\
\cline { 2 - 4 } & $\geq 150,000$ to $<200,000$ & 7 & 5.04 \\
\cline { 2 - 4 } & $\geq 200,000$ to $<250,000$ & 13 & 9.35 \\
\cline { 2 - 4 } & $\geq 250,000$ to $<300,000$ & 11 & 7.91 \\
\cline { 2 - 4 } & $\geq 300,000$ to $<350,000$ & 26 & 18.71 \\
\cline { 2 - 4 } & $\geq 350,000$ to $<400,000$ & 18 & 12.95 \\
\cline { 2 - 4 } & $\geq 400,000$ & 58 & 41.73 \\
\hline Monthly disposable income ${ }^{\text {a }}$ & $\begin{array}{l}\text { Parents and their children } \\
\text { (double income) }\end{array}$ & 23 & 19.33 \\
\cline { 2 - 4 } & $\begin{array}{l}\text { Single mothers, or single } \\
\text { mothers with their parents }\end{array}$ & 11 & 91.67 \\
\hline
\end{tabular}

Table 1. Demographic variables $\mathrm{N}=144$

Due to missing values, the total number does not represent the total percentage for some items. ${ }^{\mathrm{a}}$ Fisher's exact test, $\mathrm{P}<0.0001$

\begin{tabular}{|c|c|c|c|}
\hline Variable & Item & $\mathrm{n}$ & $\%$ \\
\hline \multirow[t]{12}{*}{ Diseases } & Cold & 63 & 44.06 \\
\hline & Pertussis & 12 & 8.39 \\
\hline & Vomiting or diarrhea & 11 & 7.69 \\
\hline & Hemolytic streptococcus infectious disease & 8 & 5.59 \\
\hline & Chickenpox & 7 & 4.90 \\
\hline & Mumps & 7 & 4.90 \\
\hline & Influenza & 4 & 2.80 \\
\hline & Bronchitis, pneumonia & 4 & 2.80 \\
\hline & Hand-foot-and-mouth disease & 4 & 2.80 \\
\hline & Exanthema subitum & 1 & 0.70 \\
\hline & Conjunctivitis & 3 & 2.10 \\
\hline & Others & 19 & 13.29 \\
\hline \multirow{3}{*}{$\begin{array}{l}\text { Subjects using the systems for reducing care } \\
\text { fees }^{\text {a }}\end{array}$} & Total & 43 & 30.5 \\
\hline & $\begin{array}{l}\text { Parents and their children (double-income } \\
\text { household) }\end{array}$ & 34 & 28.33 \\
\hline & Single mothers, or single mothers with their parents & 7 & 58.33 \\
\hline $\begin{array}{l}\text { Experiences that had ever been unable to } \\
\text { utilize sick child care }\end{array}$ & & 57 & 39.86 \\
\hline $\begin{array}{l}\text { Number of times that had ever been unable to } \\
\text { utilize sickchild care during the previous year } \\
\text { (Mean, SD). }\end{array}$ & & 2.51 & 5.42 \\
\hline \multirow[t]{4}{*}{ Reasons for unavailable sick child care } & The facility reached its maximum capacity. & 44 & 78.57 \\
\hline & $\begin{array}{l}\text { It takes time to transport my child to and from } \\
\text { the nursery, and accompany themfor a medical } \\
\text { consultation. }\end{array}$ & 2 & 3.57 \\
\hline & Financial reasons & 1 & 1.79 \\
\hline & Others & 9 & 16.07 \\
\hline
\end{tabular}

Table. 2 Cont. 


\begin{tabular}{|l|l|l|l|}
\hline $\begin{array}{l}\text { Actions taken when sick child care was unavailable } \\
\text { (Multiple answers allowed [n=57]) }\end{array}$ & The child's mother took the day off from work & 48 & 84.21 \\
\cline { 2 - 4 } & The child's father took the day off from work & 16 & 28.07 \\
\cline { 2 - 4 } & $\begin{array}{l}\text { The child was placed in the care of their } \\
\text { grandparents }\end{array}$ & 10 & 17.54 \\
\cline { 2 - 4 } & $\begin{array}{l}\text { The child's grandparents took the day off from } \\
\text { work }\end{array}$ & 5 & 8.77 \\
\cline { 2 - 4 } & The child was left at home alone & 5 & 8.77 \\
\cline { 2 - 4 } & $\begin{array}{l}\text { Babysitters (e.g., child raising helpers or } \\
\text { volunteers) were hired }\end{array}$ & 1 & 1.75 \\
\hline
\end{tabular}

Table 2. Usage of sick child care $\quad \mathrm{N}=144$

Due to missing values, the total number does not represent the total percentage for some items.

${ }^{a}$ Parents and their children (double-income household) vs single mothers, or single mothers with their parents, Fisher's exact test, $\mathrm{P}<0.0477 \mathrm{n}$

\begin{tabular}{|c|c|c|c|c|c|c|c|c|c|}
\hline Factor & Item & Factor 1 & Factor2 & Factor3 & Communarity & Mean & $\mathrm{SD}$ & $\begin{array}{l}\text { Item-Total } \\
\text { correlation }\end{array}$ & Alpha ${ }^{b}$ \\
\hline \multirow{4}{*}{$\begin{array}{l}\text { bSense of ease } \\
\text { achieved through } \\
\text { using sick child } \\
\text { care (Factor 1) }\end{array}$} & & & & & & 3.72 & 0.46 & & 0.86 \\
\hline & $\begin{array}{l}\text { Because my child } \\
\text { was taken care of by } \\
\text { professionals, I was } \\
\text { able to work free from } \\
\text { anxiety }\end{array}$ & 0.96 & 0.07 & -0.17 & 0.917 & 3.79 & 0.50 & 0.43 & \\
\hline & $\begin{array}{l}\text { As I did not have to } \\
\text { worry about leaving } \\
\text { my workplace early, I } \\
\text { could focus on my job } \\
\text { free from anxiety }\end{array}$ & 0.80 & -0.15 & 0.11 & 0.598 & 3.74 & 0.57 & 0.44 & \\
\hline & $\begin{array}{l}\text { Because specialists } \\
\text { cared for my child, } \\
\text { my child recuperated } \\
\text { from the illness }\end{array}$ & 0.67 & 0.14 & 0.17 & 0.670 & 3.62 & 0.63 & 0.61 & \\
\hline \multirow{3}{*}{$\begin{array}{l}\text { Parents' relief } \\
\text { (Factor 2) }\end{array}$} & & & & & & 3.23 & 0.75 & & 0.75 \\
\hline & $\begin{array}{l}\text { I was relieved because } \\
\text { I was able to care for } \\
\text { my child together } \\
\text { with the staff of the } \\
\text { sick child care center }\end{array}$ & -0.09 & 0.94 & 0.01 & 0.830 & 3.06 & 0.93 & 0.67 & \\
\hline & $\begin{array}{l}\text { I did not have } \\
\text { to worry about } \\
\text { causing trouble } \\
\text { for my relatives or } \\
\text { acquaintances }\end{array}$ & 0.07 & 0.63 & 0.03 & 0.459 & 3.41 & 0.83 & 0.57 & \\
\hline \multirow{3}{*}{$\begin{array}{l}\text { Benefits for } \\
\text { children (Factor } \\
\text { 3) }\end{array}$} & & & & & & 2.81 & 0.69 & & 0.72 \\
\hline & $\begin{array}{l}\text { My child did not need } \\
\text { to receive medical } \\
\text { consultation at night } \\
\text { or after hours }\end{array}$ & -0.06 & -0.09 & 0.92 & 0.775 & 2.54 & 0.98 & 0.62 & \\
\hline & $\begin{array}{l}\text { My child did not need } \\
\text { to have to refrain } \\
\text { from playing because } \\
\text { of illness }\end{array}$ & 0.07 & 0.24 & 0.54 & 0.495 & 2.56 & 0.89 & 0.67 & \\
\hline
\end{tabular}

Table. 3 Cont. 


\begin{tabular}{|c|c|c|c|c|c|c|c|c|c|}
\hline & $\begin{array}{l}\text { My child did not need to go to nursery / school by } \\
\text { pushing himself too much, in spite of illness }\end{array}$ & 0.19 & 0.19 & 0.41 & 0.381 & 3.33 & 0.81 & 0.62 & \\
\hline Scale & & & & & & 3.25 & 0.47 & & 0.82 \\
\hline
\end{tabular}

Exploratory factor analysis was conducted using unweighted least squares with promax rotation.

${ }^{\text {a }}$ Spearman's correlation coefficient; all of the probability values showed $\mathrm{P}<0.0001$.

${ }^{\mathrm{b}}$ Polychoric ordinal alpha coefficient.

Table 3. Benefits of sick child care $\quad \mathrm{N}=144$

\begin{tabular}{|c|c|c|c|c|c|c|c|c|}
\hline Factor & Item & Factor1 & Factor2 & Communarity & Mean & SD & $\begin{array}{l}\text { Item-Total } \\
\text { correlation }^{\text {a }}\end{array}$ & Alpha ${ }^{b}$ \\
\hline \multirow{5}{*}{$\begin{array}{l}\text { Care fee-related requests } \\
\text { (Factor 1) }\end{array}$} & & & & & 2.87 & 0.85 & 0.82 & 0.89 \\
\hline & $\begin{array}{l}\text { I wish that care fees } \\
\text { were fully subsidized }\end{array}$ & 0.92 & -0.11 & 0.821 & 2.71 & 1.06 & 0.80 & \\
\hline & $\begin{array}{l}\text { I wish that care } \\
\text { fees are covered by } \\
\text { insurance }\end{array}$ & 0.84 & 0.10 & 0.745 & 3.07 & 0.97 & 0.75 & \\
\hline & $\begin{array}{l}\text { I desire financial } \\
\text { support from my } \\
\text { workplace }\end{array}$ & 0.81 & -0.05 & 0.643 & 2.73 & 1.06 & 0.73 & \\
\hline & $\begin{array}{l}\text { I desire lower care } \\
\text { fees }\end{array}$ & 0.73 & 0.08 & 0.567 & 2.99 & 0.99 & & \\
\hline \multirow{4}{*}{$\begin{array}{l}\text { Desire for an increase } \\
\text { in the capacity to accept } \\
\text { children (Factor 2) }\end{array}$} & & & & & 3.37 & 0.65 & & 0.79 \\
\hline & $\begin{array}{l}\text { I desire an increase } \\
\text { in the number of care } \\
\text { facilities }\end{array}$ & 0.03 & 0.99 & 0.995 & 3.46 & 0.69 & 0.41 & \\
\hline & $\begin{array}{l}\text { I desire an increased } \\
\text { capacity to accept } \\
\text { children }\end{array}$ & -0.03 & 0.66 & 0.425 & 3.27 & 0.79 & 0.34 & \\
\hline & & & & & 3.04 & 0.64 & & 0.80 \\
\hline
\end{tabular}

Exploratory factor analysis was conducted using unweighted least squares with promax rotation.

The mean factor score significantly differed among 2 factors $(\mathrm{P}<0.0001) \quad$ (Paired $\mathrm{t}$-test).

a Spearman's correlation coefficient; all of the probability values showed $\mathrm{P}<0.0001$.

Polychoric ordinal alpha coefficient.

The mean factor score significantly differed among all 3 factors both in the odd number group and even number group, Wilcoxon rank-sum test, Odd number group vs Even number group.

Table 4. Parents' requests regarding sick child care $\quad \mathrm{N}=144$

\begin{tabular}{|l|l|l|l|}
\hline Core categories & Categories & Subcategories & Labels \\
\hline Benefits of sick child care & Parents' relief & $\begin{array}{l}\text { Sense of relief because of being } \\
\text { able to work }\end{array}$ & $\begin{array}{l}\text { Sense of ease because of being able to work } \\
\text { through using sick child care }\end{array}$ \\
\hline & & & Being able to manage work and child raising \\
\hline & & & $\begin{array}{l}\text { No need to feel reluctant to take time off } \\
\text { from work }\end{array}$ \\
\hline & & $\begin{array}{l}\text { No need to feel anxious about losing one's } \\
\text { job or trust from people at the workplace }\end{array}$ \\
\hline
\end{tabular}

Table. 5 Cont 


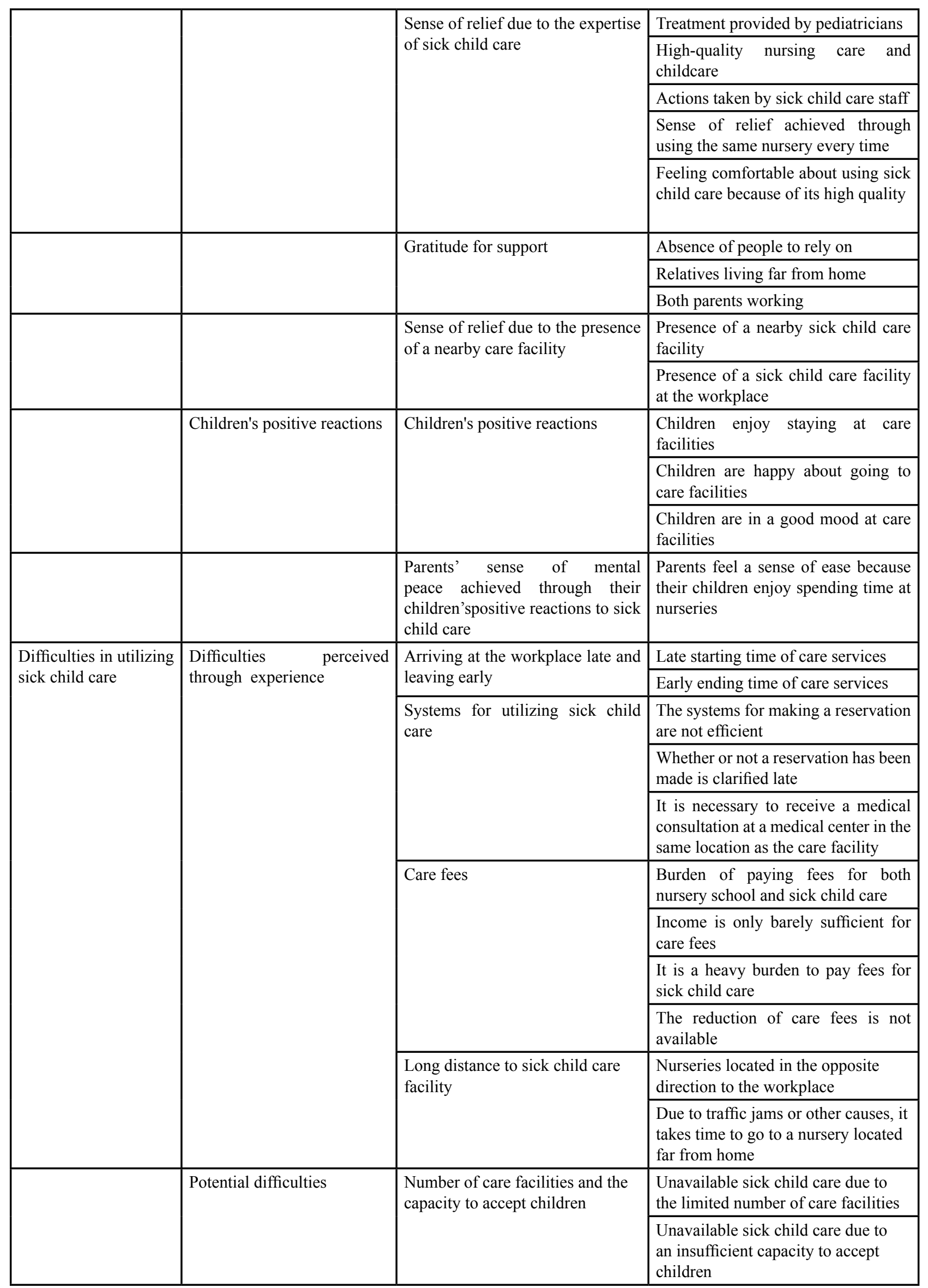

Table.5 Cont. 


\begin{tabular}{|c|c|c|c|}
\hline & & \multirow[t]{2}{*}{ Infection } & $\begin{array}{l}\text { Anxiety due to the possibility } \\
\text { that an individual's child may be } \\
\text { infected by other children }\end{array}$ \\
\hline & & & $\begin{array}{l}\text { Anxiety due to the possibility } \\
\text { that an individual's child may } \\
\text { spread their infectious disease } \\
\text { to other children }\end{array}$ \\
\hline \multirow[t]{19}{*}{ Sick child care-related requests } & \multirow[t]{11}{*}{$\begin{array}{l}\text { Requests that parents wanted to } \\
\text { make to care facilities }\end{array}$} & \multirow[t]{2}{*}{ Business hours } & $\begin{array}{l}\text { Desire for the earlier starting } \\
\text { time of care services }\end{array}$ \\
\hline & & & $\begin{array}{l}\text { Desire for the later ending time } \\
\text { of care services }\end{array}$ \\
\hline & & \multirow[t]{2}{*}{$\begin{array}{l}\text { Number of days sick child } \\
\text { care is available }\end{array}$} & $\begin{array}{l}\text { Desire for the provision of } \\
\text { care services on weekends and } \\
\text { holidays }\end{array}$ \\
\hline & & & $\begin{array}{l}\text { Desire for no regular holidays } \\
\text { on weekdays }\end{array}$ \\
\hline & & $\begin{array}{l}\text { Capacity to accept } \\
\text { children }\end{array}$ & $\begin{array}{l}\text { Desire for an increase in the } \\
\text { number of care staff members }\end{array}$ \\
\hline & & \multirow[t]{2}{*}{ Reservation systems } & $\begin{array}{l}\text { Desire for efficient reservation } \\
\text { systems }\end{array}$ \\
\hline & & & $\begin{array}{l}\text { Desire for the earlier notification } \\
\text { of whether or not a reservation } \\
\text { has been made }\end{array}$ \\
\hline & & \multirow[t]{4}{*}{ Facility systems } & $\begin{array}{l}\text { Desire for care facilities to } \\
\text { provide lunch according to } \\
\text { care service users' physical } \\
\text { conditions }\end{array}$ \\
\hline & & & $\begin{array}{l}\text { Desire for care facilities to } \\
\text { provide snacks }\end{array}$ \\
\hline & & & $\begin{array}{l}\text { Desire for the isolation of } \\
\text { children with confirmed or } \\
\text { suspected infection from other } \\
\text { children }\end{array}$ \\
\hline & & & $\begin{array}{l}\text { Desire for no age limit for using } \\
\text { sick child care }\end{array}$ \\
\hline & \multirow[t]{4}{*}{$\begin{array}{l}\text { Requests that parents wanted to } \\
\text { maketo the government }\end{array}$} & \multirow[t]{4}{*}{ Number of care facilities } & $\begin{array}{l}\text { Desire for an increase in the } \\
\text { number of care facilities }\end{array}$ \\
\hline & & & $\begin{array}{l}\text { Desire for sick child care } \\
\text { facilities to be set up in the same } \\
\text { location as nursery schools }\end{array}$ \\
\hline & & & $\begin{array}{l}\text { Desire for the environment } \\
\text { around sick child care facilities } \\
\text { to improve }\end{array}$ \\
\hline & & & $\begin{array}{l}\text { Desire for the establishment of } \\
\text { new sick child care facilities in } \\
\text { an even closer location }\end{array}$ \\
\hline & & \multirow[t]{4}{*}{ Care fees } & Desire for reduced care fees \\
\hline & & & Desire for subsidies for care fees \\
\hline & & & $\begin{array}{l}\text { Desire for no additional charge } \\
\text { for sick child care }\end{array}$ \\
\hline & & & $\begin{array}{l}\text { Desire for the reduction of care } \\
\text { fees according to the numbers } \\
\text { of accepted children and days } \\
\text { usingcare services. }\end{array}$ \\
\hline
\end{tabular}

Table 5. Benefits of sick child care $\mathrm{N}=144$ 
A polychoric correlation matrix was created for the 14 items regarding sick child care-related requests, in order to facilitate the interpretation of these items. The data obtained from these items were then subjected to exploratory factor analysis (unweighted least squares, promax rotation) (Table 4), which led to the extraction of the following 2 factors: 1) care fee-related requests, and 2) desire for an increase in the capacity to accept children.

Both the scale used and these 2 factors showed a polychoric ordinal alpha coefficient of $\geq 0.79$, and an item-total correlation coefficient of $\geq 0.34$, which established the scale's reliability. The score for Factor 2 was significantly higher than that for Factor $1(\mathrm{P}<0.0001)$.

\section{Qualitative Data}

The free descriptions were divided into the following 3 core categories: the 1) benefits of sick child care, 2) difficulties in utilizing sick child care, and 3) sick child care-related requests (Table 5). These core categories comprised 6 categories consisting of 19 subcategories and 52 labels. In this article, the core categories, categories, subcategories, and subjects' descriptions are shown as \{ \}, [ ], «", and " ", respectively.

\section{Benefits of sick child care}

The \{benefits of sick child care\} comprised [parents' relief] and [children's positive reactions]. Through utilizing sick child care, parents showed a sense of relief due to being able to work as well as the expertise and convenience of such care, and were grateful to care staff as child raising supporters. In addition, they felt a sense of mental peace resulting from children's positive reactions to sick child care.

«Sense of relief because of being able to work»

"I need sick child care to manage child raising and work, and to develop my career."

"Due to sick child care, I am able to continue balancing life and work"

«Sense of relief due to the expertise of sick child care»

"I am relieved that my child is able to receive appropriate treatment and medical consultations at the nursery."

«Gratitude for support»

"I could not ask my parents to look after my child as they live in a different prefecture. However, due to sick child care, I was able to return to work."

«Parents' sense of mental peace achieved through their children's positive reactions to sick child care»

"I am relieved that my child is not reluctant to go to the nursery when I cannot look after them. I am very grateful to the nursery staff."

\section{Difficulties in utilizing sick child care}

Parents' \{difficulties in utilizing sick child care\} comprised [difficulties perceived through experience] and [potential difficulties]. Parents felt difficulty utilizing such care, for reasons such as the possibility of arriving at the workplace late or having to leave early, slowness in being able to clarify whether or not care services are available, inefficient systems for making a reservation for such services, a prolonged time required to go to care facilities far from home, financial burden (fees for both nursery school and sick child care), or their low income which was only barely sufficient for care fees. Regarding the future usage of sick child care, parents were concerned about infection risks, and the possibility of being unable to use such care due to the limited number of care facilities or an insufficient capacity to accept children.

[Difficulties perceived though experience]

"Arriving at the workplace late and leaving early»

"I always arrive at my workplace late because of the delay in being able to clarify whether or not care services are available."

«Systems for utilizing sick child care»

"When I apply for care services the day before, I am often placed on a waiting list. In this case, I have to be prepared for both the sick child care facility being available and unavailable. I am very anxious while waiting for a call from the facility in the morning."

«Care fees»

"In general, my household income is not sufficient for living costs after paying fees for both nursery school and sick child care."

"Sick child care may cost more than 7,000 yen when 2 or more of my children use it. My daily salary is only barely sufficient for this cost." "It is impossible to make a living unless both my spouse and I work. Sick child care fees are expensive, but we have no choice but to use it."

«Long distance to sick child care facility»

"The sick child care facility is located in the opposite direction to my workplace. Therefore, when using sick child care, I need to take three-hour leave."

[Potential difficulties]

«Number of care facilities and the capacity to accept children»

"When my child rapidly develops a fever but I cannot take the day off from work, they are sometimes not accepted by the nursery because the maximum capacity of children has been reached. I have no idea what to do in such circumstances."

\section{Requests regarding sick child care}

The \{sick child care-related requests\} comprised the following 2 categories: [requests that parents wanted to make to care facilities] and [requests that parents wanted to make to the government]. The requests to care facilities included longer business hours, an increased number of days sick child care is available (weekends and holidays), increase in the capacity to accept children, efficient reservation systems, improved facility systems, the provision of lunch and snacks, isolation of infected children from other care service users, and a higher upper age limit for utilizing care services. The requests to the government included an increase in the number of care facilities, the reduction of care fees, and increased subsidies for these fees.

[Requests that parents wanted to make to care facilities]

«Business hours»

"I wish for the nursery to open half an hour earlier. That way, I would not be late for work."

«Reservation systems»

"I would appreciate it if there was an online system that shows the currently available sick child care facilities in town, and helps us to make a reservation."

«Facility systems»

"I would appreciate it if the nursery provided lunch according to children's disease conditions. I would not mind paying for this."

"I wish for sick child care to be available until reaching the first year of junior high school."

[Requests that parents wanted to make to the government] «Care fees»

"My salary is only barely sufficient for sick child care fees. I desire reduced fees."

"I would appreciate it if sick child care fees were reduced in the same way as nursery school fees."

\section{Discussion}

Characteristics of the users of care services, and their benefits

As was the case in previous studies [5,10], sick child care was used mainly by children from double-income nuclear families or single-mother households, primarily because of infectious diseases. Concerning the benefits of sick child care, the results of our study suggest that children can benefit from the expertise of such care, and parents can receive support for work and child raising when they have no relative to look after their children. Parents viewed the sense 
of relief achieved by utilizing sick child care as the most beneficial factor of such care. Such a sense refers to feeling comfortable about the use of appropriate and professional childcare, and being able to work without worrying about the possibility of leaving the workplace early. In addition, parents considered sick child care to be helpful in that they do not have to rely on relatives, and that they do not need to look after their children by themselves. Furthermore, parents felt a sense of mental peace resulting from: 1) a reduced burden on sick children (no need to attend nursery school or receive a night-time medical consultation), 2) their normal development, and 3) their positive reactions to sick child care.

These positive views (regarding sick children's early recovery and normal development, as well as child raising-related advice given to parents) are consistent with those reported in previous studies investigating care provided by nurses and nursery staff [4,11-14]. The results of these studies and the present study suggest that total care for sick children and child raising support for their parents become the basis for work support.

Some of the effective measures to facilitate sick child care are the systems for reducing care fees. In the present study, approximately $60 \%$ of the single mothers were using these systems, and only one subject had been unable to utilize sick child care for financial reasons. Sick children are a major risk factor not only for a reduced income, but also for dismissal from work [9].

In particular, such children are a serious issue for single mothers who are non-regular employees, or those with a low income [15]. In the present study, for more than $90 \%$ of the single mothers, the monthly disposable income was less than 300,000 yen, which is lower than that earned by households with children $(330,000-375,000$ yen, which is equivalent to an average annual income of 6.07 million yen) [16]. Therefore, for low-income parents, such as single mothers, the systems for reducing care fees help to ensure a stable income and job security.

\section{Difficulties in and requests regarding the use of sick child care}

During the previous year, approximately $40 \%$ of the subjects had been unable to use sick child care at least once and, for $80 \%$ of such individuals, the reason for unavailable care services was because of overcrowded facilities. In such circumstances, as was the case in previous studies $[17,18]$, more than $80 \%$ of the mothers took the day off from work. Unavailable sick child care may become a serious problem for parents (e.g., single mothers) who have nobody to look after their children. When sick child care is inaccessible, parents usually have to choose one of the following 3 options: 1) take the day off from work, 2) leave their children at home alone, or 3) take them to their workplace.

The second option was noted in both the present study and previous studies despite a major risk imposed on children $[9,19]$. In the present study, the average annual number of days using sick child care was 8.35 (1.89 days/time $\times 4.42$ times/year). Although the annual number of days children aged 0-6 years are absent from nursery school ranges from 10 to 22 [19], parents are not able to take sufficient child care leave (up to 5 days each year when they have one preschool child) [20]. In the U.S. and U.K., it is prohibited to leave children with a health risk at home alone [21,22]; however, Japan does not have such a legal regulation. From the perspective of child safety, it is imperative to increase the capacity to accept children, number of care facilities, and upper age limit for using these facilities.

Approximately $70 \%$ of the subjects arrived at their workplace late or had to leave early when using sick child care. Such interference with work is caused by the time required to go to a sick child care facility, and short business hours at the facility. The business hours of sick child care facilities (10 hours) [23] are shorter than those of nursery schools (11.6 hours) [24]. Furthermore, some parents utilize sick child care facilities located far from home, for reasons such as a shortage of such facilities and an insufficient capacity to accept children. It is a heavy burden for sick children to go to a care facility far from home, and stay there for a long time. Moreover, when an individual uses a sick child care facility located in a different municipality without the specified agreement because of overcrowded care facilities in their home municipality, they will not be able to use the systems for reducing care fees.

For parents who suffered from various difficulties, the strongest desire was to increase the number of care facilities and the capacity to accept children. From the perspectives of the safety of and care for sick children, and high-risk households (e.g., single mothers and low-income parents), it is imperative to increase the number of care facilities, the capacity to accept children, and the number of municipalities in which care services are accessible to service users from each municipality.

Concerning the cost of sick child care (standard fee of 2,000 yen per day), subjects reported an increased financial burden due to service utilization by more than one child at any one time, the repeated usage of such care, and fees for nursery school in addition to those for sick child care. In Japan, for households who earn a mean annual income of 6.07 million yen, the standard monthly childcare fee for the first child aged $<3$ years is 44,500 yen, and that for the first and second child aged $<3$ years is 66,750 yen [1]. In Prefecture A, the lowest hourly wage is 769 yen [25]; therefore, the daily wage of part-time workers may be only barely sufficient for daily fees for sick child care (2,000 yen). When a child develops influenza, due to which they will be absent from their nursery school for at least 5 days, a sick child care fee of 10,000 yen is necessary for the child [26]. Thus, for people who are unable to use the systems for reducing care fees, it may be very difficult to pay sick child care fees (repeated usage of such care, and service utilization by more than one child at any one time), in addition to nursery school fees. Care services users may desire the government to provide comprehensive support for sick child care, as is the case with pediatric healthcare and nursery school [27].

In the present study, we investigated only one prefecture employing a system for reducing care fees; hence, due to the small sample size, we were not able to clarify differences according to the type of household or presence/absence of the above-mentioned agreement. To design policies based on the needs of care service users, it is necessary to investigate the characteristics of care facility users, and assess the existing care-related measures.

\section{Conclusion}

Sick child care was utilized mainly by children from doubleincome nuclear families or single-mother households, primarily because of infectious diseases. The systems for reducing care fees were used by approximately $60 \%$ of the single mothers. Parents were able to work free from anxiety due to child raising support, and the benefits that their children received from sick child care. On the basis of difficulties in utilizing sick child care, parents desired improved care services. The results of this study suggest that, to facilitate sick child care based on the needs of service users, there is a need to increase both the number of care facilities and the capacity to accept children, improve the system for reducing care fees, and increase the number of municipalities in which such care is accessible to service users from each municipality.

\section{Acknowledgement}

We are very grateful to all those who participated in this study. This study was funded by Grants-in-Aid for scientific research expenses of the Japan Society for the Promotion of Science (25463472).

Conflict of Interest Disclosure: The authors have no conflicting interest in this study.

Author's Contributions: R. S. and I. S. contributed to the conception and design of the study; R. S., H. W. and M. Y. contributed 
to the acquisition, analyses, and interpretation of the data, as well as the drafting of the manuscript; I. S. contributed to the supervision of the drafting and critical revision of the manuscript; and all the authors have read the manuscript and have approved this submission.

\section{References}

1. Child Raising Center, Cabinet Office, Government of Japan (2015) New child raising support system.

2. Director-General of the Equal Employment, Children and Families Bureau, Ministry of Health, Labour and Welfare (2015) Provision of sick child care.

3. Cabinet Office (2013) Sick child care.

4. Japan Sick Childcare Association (2016) Concept of sick child care.

5. Yamada Y, Harada K (2009) Roles of sick child care based on a questionnaire survey involving care users. Child Health Ishikawa 21: 7-11.

6. Ishino A, Kato H, Matuda H, Bakke M (2013) Work-life balance and needs in parents used sick childcare service. J Child Health 72: 305-310.

7. Tanimoto H, Tanimoto K (2016) Need and problems of the sick child care - Considering the results of a questionnaire survey of the parents. J Child Health 65: 593-599.

8. Tanihara M, Abe H, Mori T, Okada K (2010) Parents' response to their sick child and the current status of sick-child-care support needs. Kawasaki Med Welf J 19:2, 411-418.

9. Kamimura A, Kawamoto M, Nagamatsu S, Takahata T, Yokoyama M, et al. (2007) Two-year experience of operating a sick child care facility -Based on past records and the results of a questionnaire survey involving care users-. J Saitama Med Soc 41:4, 309-312.

10. Nakagawa S, Katsura T (2004) A current situation and problems of the nursery care of sick children - Considering the result of a questionnaire survey of their parents and guardians. J Child Health 63: 389-394.

11. Kanda T, Miyazu S (2010) Research on childcare nursing at the child care room for sick children: Based on the viewpoint of child care support. Bull Fac Educ, Hirosaki Univ 103: 105-109.

12. Tanaka Y (2011) The perception of services in nurses as to the day care for sick children. J Child Health 70: 365-370.

13. Fujiwara Y (2007) The role of an institution for day care for sick children: Focusing on evaluation of the staff. Jpn Soc Res Early Child Care Educ 45: 183-190.

14. Kanaizumi S, Nakashita T, Yajima M, Ohno A (2003) Characteristics of nursing and nursing intervention skills required in a nursery room for children recovering from common illnesses. Bull Gumma Paz Gakuen College 5: 87-97.

15. Ministry of Health, Labour and Welfare (2012) Nationwide survey on fatherless families for 2011.

16. Ministry of Health, Labour and Welfare (2011) Overview of comprehensive survey regarding living conditions for 2010.

17. Sato M (2006) Research into the needs of day nursery users for children with sickness. J Jpn Red Cross Toyota College Nurs 2: 29-34.

18. Arai K, Yasunari T, Ota C, Sakashita R, Katada N (2012) Responses to illness among the children of working mothers and their needs. J Gen Fam Med 35: 27-36.

19. Fukada M, Minamimae K, Kasagi T (2001) Analysis of a method of sick child care and nursing role. J Yonago Med Assoc 52: 183-195.

20. Ministry of Health, Labour and Welfare (2010) Outline of the child care and family care leave law.
21. Child welfare information gateway (2013) Leaving your child home alone.

22. National Society for the Prevention of Cruelty to Children (2016) Staying home alone.

23. Japan Sick Childcare Association (2009) Current state of and issues regarding sick child care.

24. Japan National Council of Social Welfare, National Child Care Council (2012) Nationwide report on the characteristics of childcare centers for 2011.

25. Hiroshima Labor department, Ministry of Health, Labour and Welfare (2016) Lowest wage in Hiroshima Prefecture.

26. Ministry of education (2013) Infectious diseases that should be prevented at schools.

27. Ministry of Health, Labour and Welfare (2015) Survey of subsidies for medical fees for infants -Results of the survey. 